\title{
Influence of Salary Administration and Conflicts Management on Organizational Performance
}

\author{
Ojo Adeshina Akinwumi ${ }^{1}$, Salinsile Mustapha Tunde ${ }^{2}$, Jane Roli Adebusuyi ${ }^{3}$, \\ Abifarin Olusola Michael $^{2}$ \\ ${ }^{1}$ Department of Psychology, Faculty of Management and Social Sciences, Leads City University, Ibadan, Nigeria \\ ${ }^{2}$ School of Business (MBA), University of Ibadan, Ibadan, Nigeria \\ ${ }^{3}$ Department of Sociology, Faculty of Management and Social Sciences, Leads City University, Ibadan, Nigeria
}

\section{Email address:}

Pivotwws1@gmail.com (O.A. Akinwumi)

\section{To cite this article:}

Ojo Adeshina Akinwumi, Salinsile Mustapha Tunde, Jane Roli Adebusuyi, Abifarin Olusola Michael. Influence of Salary Administration and Conflicts Management on Organizational Performance. International Journal of Psychological and Brain Sciences.

Vol. 6, No. 1, 2021, pp. 1-6. doi: 10.11648/j.ijpbs.20210601.11

Received: December 15, 2020; Accepted: December 31, 2020; Published: January 15, 2021

\begin{abstract}
Frequent organizational conflict resulting from continuous, agitation by workers for improved working conditions such as increment in salaries, gratuity, pension benefits, allowances and other interests have led to a down toll which eventually affects organizations performance and has taken a comparative nosedive sequence which is a confirmation that organizational performance is enhanced through effective conflict management. The study investigated the influence of salary administration and conflict management on organizational performance among university college hospital staff. The theories of Goal Setting, Capital and Abraham Maslow's provided the framework for this research. A cross sectional survey with an expost facto design was utilized in gathering data from University College Hospital (UCH) through purposive sampling technique. A total of two hundred two four (224) employees of UCH were sampled and data gathered was analyzed using t-test for independent sample and multiple regression analysis. Findings revealed that conflict management had a significant influence on organizational performance among employees in $\mathrm{UCH}[\mathrm{t}(222)=2.98 ; \mathrm{P}<.01]$. Also, salary administration had a significant influence on organizational performance among employees in UCH $[\mathrm{t}(222)=4.32 ; \mathrm{P}<.01]$. In addition, when combined, conflict management and salary administration jointly influence organizational performance $[\mathrm{R}=.32 ; \mathrm{R} 2=.10 ; \mathrm{F}$ $(2,221)=11.92 ; \mathrm{P}<.01]$. The study concluded that conflict management and salary administration were significant determinants of organizational performance. It was therefore recommended that UCH management should endeavour to encourage utilization of integrating employees to work together and learn to tolerate each other.
\end{abstract}

Keywords: Organizational Performance, Conflict Management, Salary Administration, Health Workers

\section{Introduction}

Over the last two decades, the study of organizational performance has drawn the attention of numerous organizational researchers. The growing interest is largely due to the advantages linked to organizational performance. Organisational performance refers to how well a firm is doing in terms of making profit, return on investment, and retention of employees as well as having a good reputation from their host community. It can also be perceived as the achievement of objectives that was set from the inception of a business year or quarterly depending on the type of activities embarked which explain that organizational performance consists of three basic fields of firms results: (a) financial performance (profits, return on assets, return on investment, etc.); (b) performance of the product market (sales, market share, etc.); and (c) return on shareholders (total shareholder return, economic value added, etc.) [9]. From the foregoing, it can be viewed that when firms are making progress especially meeting their goals or objectives; then they are perceived to be performing. This performance can be in the areas of product development, diversification, as well as penetration into other countries with or without the same business model. It was also argue that Organisational performance is very significance for any successful 
organizations. Performance has resulted to firms profitability, increase in shareholder base as well as diversification into different areas of related businesses [15].

It was also argue that if an organization's workers are to fulfill their duties and make positive contributions to the achievement of organizational goals, they need to learn the necessary skills and expertise through Conflicts management and salary administration [18].

Conflict is an unavoidable aspect of a hospitality organizational life and there are a variety of distinctive features in the world of the hospitality industry that can lead to the creation of conflict situations. This include the triadic relationship between management, workers, and clients; the pace of activity, creating stress and strain for the participants' operatives. In certain cases, the degree of interdependence between departments is inevitably high if the client is to obtain a satisfactory service, thereby raising the tendency of conflict to occur [18]. Conflict is inevitable among workers in an organization. If it is properly handled, it can provide a catalyst for improvement and will have a beneficial effect on the organization's employee satisfaction and performance. Conversely, unmanaged conflict negatively impacts both employee satisfaction and job performance. When organizational leaders ignore workplace conflict, they send a message that unsatisfactory job performance and inappropriate behavior are acceptable. Properly managed conflict promotes open communication, collaborative decision making, regular feedback, and timely resolution of conflict. Open contact and teamwork increase the flow of new ideas and reinforce working relationships, which can have a positive impact on the morale of employees. Daily input and prompt dispute resolution have the ability to increase the employee satisfaction and job performance. Another aspect that may affect organizational efficiency, apart from conflict, is wage administration. [11] noted that the administration of wages and salaries relates to the development, implementation and continuing maintenance of a base pay system. The core goal or aim of the administration of wages and salaries is to provide both competitive and equal pay. Procedures, strategies, plans and schemes that give rise to pay policies apply to wage and salary administration activities. These laws, public or private as the case may be, set the overall course of pay within the organizations or establishment [2]. The definition of pay policies parallels the actual implementation of a base pay scheme. It was also argued that the developments in Nigeria's wage and salary administration are unjustified by the nation's actual socioeconomic growth [1]. In other words, the importance of increased wages for workers is declining. Studies have investigated organizational performance using different population such as managers, government workers and insurance workers $[13,6,5,9]$. However to the researcher knowledge, no study has examined the influence of Conflicts management and salary administration on organizational performance among health workers. Outcome of the study will help proffer mechanisms that would help improve and sustain organizational performance in Nigeria.

\section{Literature Review}

The impact of organizational conflict on employee job performance among a sample size of 110 was examined Results showed that unclear responsibilities, poor reward system, and lack of group cohesiveness, are responsible for organizational conflicts [9]. The effect of conflict management on employee's performance was examined. The study found that there is a significant relationship between conflict management and employees performance [21]. The conflict management on organizational performance of banks in Nigeria was also investigated. The result of the study found that there was a significant positive relationship between conflict management and organizational performance [7]. The impact of workplace conflict management on organizational performance in a Nigerian manufacturing firm was examined. Participants comprised 250 employees. The results found that there was a significantly positive relationship between conflict management strategies and organizational performance. conflict management on employees' performance among 50 purposively selected sample respondents consisting of 25 managerial employees and 25 non-managerial employees [17]. The result found that there was significant relationship exists between conflict management strategies and employees' performance [14].

Employee performance is influenced by intra-group conflicts, inter-organizational conflicts and conflict resolution techniques The results of this study showed that inadequate conflict management resulting from interorganizations, intra-group relationships and individual employees as well as ineffective conflict resolution mechanisms have a direct impact on the performance of employees [4]. The study investigate relationship between conflict management strategies and the performance of employees and employee/management perception of the efficacy of conflict management strategies. The data analysis results showed that there is an essential connection between conflict management techniques and the success of employees. [10] Investigated the effect of organizational conflict on organizational performance. The research found that organizational conflict has negative influence on organization performance [8].

Based on the reviewed study, the following hypotheses were postulated

1. Respondents who have high salary administration will significantly report higher organizational performance than respondents who report low salary administration.

2. Respondents who have effective conflict management will significantly report higher organizational performance than respondents who report ineffective conflict management.

3. There will be significant joint role of conflict management and salary administration on organizational performance among health workers. 


\section{Methods and Materials}

\subsection{Design}

A descriptive survey design was adopted by the study. This is because the questionnaire was used to collect information on the effect of wage administration on organizational efficiency and conflict management.

\subsection{Population}

The research population of the study comprised of University College Hospital employees. There are over 5,000 employees, currently working in University College Hospital as at the time of the study.

\subsection{Sample and Sampling Technique}

The study used a sampled size of 250 participants. Purposive sampling technique was adopted in which the researchers already know some features of the participants.

\subsection{Measures}

To collect data from respondents, the study used a selfdesigned questionnaire. The questionnaire was divided into three parts. Section A of the questionnaire entails the socio demographic factors of the respondents which consist of age, gender, marital status, job status and work experience. Section B of the instrument consists of 6 items organizational performance scale. Section C consists of 6 items conflict management style while section D consists of 6 items salary administration scale. All the scales were scored on a five port likert scale ranging from Strongly Agree, to Strongly Disagree. A pilot study was conducted using 15 workers that were not part of the main study. The study got a reliability coefficient of 0.68 for the organizational performance scale, 0.79 for the conflict management style and 0.91 for the salary administration scale.

\subsection{Procedure}

Permission to conduct the study was granted by the hospital management through the university administration. Furthermore, the researcher explained the goals and purpose of the study to consented participants and also assures them of their confidentiality of their responses. The respondents were also informed that they can withdraw from the study anytime they so wish to do so. The participants completed the questionnaire after the close of work while some took it home and return the following day. Two hundred and fifty total questionnaires were distributed across the hospital departments but only two hundred and twenty four were retrieved while twenty six were either not returned or have incomplete responses. The collected questionnaires were subjected to statistical analysis.

\subsection{Statistical Analysis}

Statistical analysis of the collected data was carried out using the IBM SPSS Statistics 24 version. The review of sociodemographic variables and hypotheses in the study was based on descriptive and inferential statistics. In order to evaluate the demographic features of the respondents, descriptive statistics were used whereas inferential statistics were used to test the hypotheses. Hypothesis one and two was tested using t-test for independent measure while hypothesis three was tested using multiple regression analysis.

\section{Results}

Table 1. Socio-Demographic Information of Participants.

\begin{tabular}{|c|c|c|c|c|}
\hline SN & Variable & Response & Frequency & Percentage \\
\hline \multirow{5}{*}{1} & \multirow{5}{*}{ Age } & Less than 25 years & 19 & 8.5 \\
\hline & & 25-29 years & 75 & 33.5 \\
\hline & & 30-34 years & 81 & 36.2 \\
\hline & & 35-39 years & 22 & 9.8 \\
\hline & & 40 years and above & 27 & 12.1 \\
\hline \multirow{2}{*}{2} & \multirow{2}{*}{ Gender } & Male & 180 & 80.4 \\
\hline & & Female & 44 & 19.6 \\
\hline \multirow{4}{*}{3} & \multirow{4}{*}{$\begin{array}{l}\text { Academic } \\
\text { qualification }\end{array}$} & SSCE & 19 & 8.5 \\
\hline & & $\mathrm{ND} / \mathrm{NCE}$ & 46 & 20.5 \\
\hline & & $\begin{array}{l}\text { HND/University } \\
\text { degree }\end{array}$ & 134 & 59.8 \\
\hline & & Postgraduate & 25 & 11.2 \\
\hline \multirow{9}{*}{4} & \multirow{10}{*}{ Job status } & Engineer & 55 & 24.6 \\
\hline & & Cleaner & 4 & 1.8 \\
\hline & & Account & 19 & 8.5 \\
\hline & & Quality Assurance & 8 & 3.6 \\
\hline & & Human Resource & 14 & 6.3 \\
\hline & & Contract staff & 50 & 22.3 \\
\hline & & Sales rep & 33 & 14.7 \\
\hline & & Marketing & 18 & 8 \\
\hline & & Microbiologist & 14 & 6.3 \\
\hline \multirow{6}{*}{5} & & Health worker & 9 & 4 \\
\hline & \multirow{4}{*}{$\begin{array}{l}\text { Work } \\
\text { Experience }\end{array}$} & Less than 5 years & 125 & 55.8 \\
\hline & & 5-9 years & 58 & 25.9 \\
\hline & & 10-14 years & 21 & 9.4 \\
\hline & & 15 years and above & 20 & 8.9 \\
\hline & Total & & 224 & 100 \\
\hline
\end{tabular}

Table 1 presents frequency distribution of participants' socio-demographic characteristics. It is shown that more of the respondents $81(36.2 \%)$ indicated to be between 30 and 34 years old, $75(33.5 \%)$ were between 25 and 29 years old, $27(12.1 \%)$ were 40 years and above, $22(9.8 \%)$ were between 35 and 39 years old, while the other 19 (8.5\%) indicated to be less than 25 years old. As regards gender distribution, more of the respondents $180(80.4 \%)$ indicated to be males, while the other $44(19.6 \%)$ signified to be females. As regards academic qualification, more of the participants $134(59.8 \%)$ indicated to be $\mathrm{HND} /$ University degree holders, $46(20.5 \%)$ were $\mathrm{ND} / \mathrm{NCE}$ holders, 25 $(11.2 \%)$ were postgraduate degree holders, while the other 19 $(8.5 \%)$ indicated to be SSCE holders.

Further from Table 1, more of the respondents 55 (24.6\%) indicated to be engineers, $50(22.3 \%)$ indicated to be contract staffs, $33(14.7 \%)$ indicated to be sales representatives, 19 
$(8.5 \%)$ indicated to be in the accounting section, $18(8 \%)$ signified to be in the marketing department, $14(6.3 \%)$ signified to be microbiologists in NBC, another $14(6.3 \%)$ were in Human Resources, 9 (4\%) were health workers, 8 $(3.6 \%)$ were quality assurance officers, while the other 4 $(1.8 \%)$ indicated to be cleaners. Finally, as regards work experience, more of the respondents $125(55.8 \%)$ indicated to have less than 5 years of work experience, $58(25.9 \%)$ had between 5 and 9 years of work experience, 21 (9.4\%) had between 10 and 14 years of work experience, while the other $20(8.9 \%)$ indicated to have 15 years and above working experience.

\subsection{Hypothesis One}

Respondents who have high salary administration will significantly report higher organizational performance than respondents who report low salary administration.

Table 2. T-test for Independent Sample Summary Table Showing the Influence of Salary Administration on Organizational Performance.

\begin{tabular}{|c|c|c|c|c|c|c|c|}
\hline Dependent & Salary Administration & $\mathbf{N}$ & Mean & SD & $\mathbf{T}$ & Df & $\mathbf{P}$ \\
\hline & High & 124 & 24.32 & 7.09 & & & \\
\hline Organizational Performance & Low & 100 & 20.22 & 5.43 & 4.32 & 222 & $<.01$ \\
\hline
\end{tabular}

Table 2 presents results on the influence of salary administration on organizational performance. It is shown that salary administration had significant influence on organizational performance among employees in $\mathrm{UCH}[\mathrm{t}$ $(222)=4.32 ; \mathrm{P}<.01]$. Further, high salary administration translated to higher organizational performance (Mean = 24.32; $\mathrm{SD}=7.09$ ) than low salary administration (Mean $=$
20.22; $\mathrm{SD}=5.43)$.

\subsection{Hypothesis Two}

Respondents who have effective conflict management will significantly report higher organizational performance than respondents who report ineffective conflict management.

Table 3. T-test for Independent Sample Summary Table Showing the Influence of Salary Administration on Organizational Performance.

\begin{tabular}{|c|c|c|c|c|c|c|c|}
\hline Dependent & Conflict management & $\mathbf{N}$ & Mean & SD & $\mathbf{T}$ & Df & $\mathbf{P}$ \\
\hline \multirow{3}{*}{ Organizational Performance } & Effective & 122 & 27.22 & 8.09 & \multirow{3}{*}{2.98} & \multirow{3}{*}{222} & \multirow{3}{*}{$<.01$} \\
\hline & & & & & & & \\
\hline & Ineffective & 102 & 22.22 & 8.32 & & & \\
\hline
\end{tabular}

Table 3 presents results on the role of conflict management on organizational performance. It is shown that conflict management had significant influence on organizational performance among employees in UCH [t (222) = 2.98; $\mathrm{P}<.01]$. Further, effective conflict management translated to higher organizational performance $($ Mean $=27.22 ; \mathrm{SD}=8.09)$ than ineffective $($ Mean $=22.22 ; \mathrm{SD}=8.32)$.

\subsection{Hypothesis Three}

There will be significant joint role of conflict management and salary administration on organizational performance among health workers.

Table 4. Multiple Regression Summary Table Showing Conflict management and Salary Administration Predictors of Job Performance.

\begin{tabular}{|c|c|c|c|c|c|c|c|c|}
\hline Dependent & Predictors & B & t-value & $\mathbf{P}$ & $\mathbf{R}$ & $\overline{\mathbf{R}^{2}}$ & $\mathbf{F}$ & $\mathbf{P}$ \\
\hline \multirow{3}{*}{ Organizational performance } & Conflict management & .02 & .30 & $>.05$ & \multirow{3}{*}{.32} & \multirow{3}{*}{.10} & \multirow{3}{*}{11.92} & \multirow{3}{*}{$<.01$} \\
\hline & & & & & & & & \\
\hline & Salary Administration & .31 & 4.64 & $<.01$ & & & & \\
\hline
\end{tabular}

Table 4 presents results on the joint and independent influence of conflict management and salary administration on organizational performance among employees in University College Hospital. It is shown that conflict management and salary administration had significant joint influence on organizational performance $\left[\mathrm{R}=.32 ; \mathrm{R}^{2}=.10 ; \mathrm{F}\right.$ $(2,221)=11.92 ; \mathrm{P}<.01]$. When combined, conflict management and salary administration accounted for about $10 \%$ variance in organizational performance. However, only salary administration had independent influence on organizational performance $[\beta=.31 ; \mathrm{t}=4.64 ; \mathrm{P}<.01]$.

\section{Discussion}

The study investigated the influence of salary administration and conflicts management on organizational performance among health workers in Ibadan. Based on the postulated hypothesis, the first hypothesis found that respondents with perceived high salary administration tend to report high organizational performance. The study finding was in accordance with the study who found that wages and salaries has significant relationship with workers performance [20]. The study findings was also in line who found that salary administration influence organizational performance [5]. The second hypothesis found that respondents who perceive effective conflict management tend to report high organizational performance than respondents who perceived ineffective conflict management. This study finding was in accordance with the study of who also found significant relationship between conflict management and employees' performance [22]. tAlso, the findings were also in line which found positive relationship 
between conflict management and organizational performance [8]. The third hypothesis found that there was joint influence of salary administration and conflicts management on organizational performance among health workers. The study also found a joint role of conflict management strategies and wages and salary administration on organizational performance [18]. It was also found that conflict management and salary has a joint influence on employee's performance [15].

\section{Conclusion}

The study concluded that salary administration had significant influence on organizational performance which implies that when salary administration is high, there is higher organizational performance than when salary administration is low. The study also concludes that conflict management was a significant determinant of organizational performance meaning that when conflict is effectively achieved, then organizational performance is highest than when conflict is ineffective. Furthermore, conflict management and salary administration were significant joint determinants of organizational performance. However, only salary administration had significant independent influence on organizational performance.

\section{Recommendations}

The study therefore recommends that $\mathrm{UCH}$ management should endeavor to encourage utilization of integrating employees to work together and learn to tolerate each other. Also, the study recommends that organizations try as much as possible to identify the dynamics in the organization and try to understand what conflict management style fits best to the organization. Finally, salary administration should be done fairly and without injustice in the organization as this will further increase the organizational performance.

\section{References}

[1] Agbonifoh, B. A., Agbadudu, A. B., \& Iyayi, F. I. O. (2005). Management: A Nigerian perspective. Lagos: Malthouse Press Ltd.

[2] Agburu, J. I. (2012). Recent trends in wage and salary administration in Nigeria: A synopsis on theoretical and empirical challenges. International Journal of Basic and Applied Sciences, 1 (2), 244-255.

[3] Awan, K., \& Anjum, E. (2015). Human Resource Management in a Business Context: Third Edition. London: Thompson Learning.

[4] Charles, M. I. \& Mary, R. (2013). Effects of work place conflicts on employee performance in the air transport industry in Kenya. Prime Journal of Business Administration and Management (BAM), 3 (6), 1083-1089.

[5] Chukwudi F., Odogwu C., \& Adedehinbo E. (2012). Motivation and Employees' Performance in the Public and
Private Sectors in Nigeria. International Journal of Business Administration 3 (1) DOI: 10.5430/ijba.v3n1p31.

[6] Cross, O (2018). Effects of Training on Organizational Performance. Asian Journal of Business and Management 06 (05), 2-13.

[7] Edeh, O., \& Nwaji, C. (2017). Employee Training and Organisational Performance of Selected Deposit Money Banks in Abia State, Nigeria. ASPL International Journal of Management Science, 6 (2), 01-13.

[8] Emmanue, 1 O., \& Babatunde, H. A. (2015). Effect of conflict management on the Performance of financial service organization in Nigeria: An Empirical Study Of Access Bank Plc. International Journal of Economics, Commerce and Management, 3 (7), 260-272.

[9] Hotepo, O. M., Asokere, Abdul-Azeez. A., \& Ajemunigbohun A. (2010). Empirical study of the effect of conflict on organizational performance in Nigeria. Business and Economics Journal, 12, 1-9.

[10] Ileka, N., \& Muogbo, U (2020). Wages And Salary Administration And Employee Performance In Selected Government Ministries In Anambra State. International Journal of Innovative Development and Policy Studies 8 (1), 70-80.

[11] Mba O. (2013). Conflict management and employees performance in Julius Berger Nigeria PLC. Bonny Island. International Journal of Academic Research in Management (IJARM), 2 (4), 126-139.

[12] Nwachukwu, C. C. (2009). Human resource management. Port Harcourt: Davidstones Publishers Ltd.

[13] Nwokorie E. (2017). Impact of organizational conflict on employee job performance in selected hotels (in Lagos Nigeria). TURIZAM, 21 (1), 45-64.

[14] Ogbu, J., \& Osanaiye, I (2017). Impact of Employee Training on Organizational Performance A Study of Selected Insurance Firms in Abuja-Nigeria. European Journal of Business and Management, 9 (14) 64-72.

[15] Okechukwu, A. (2013). Conflict management and employees performance in Julius Berger Nigeria PLC. Bonny Island. International Journal of Academic Research in Management (IJARM), 2 (4), 125-139.

[16] Okpara, J. O. \& Pamela, W. (2008). HRM practices in a transition economy: Challenges and prospects. Management Research News, 31 (1), 57-76.

[17] Olaniyan, D. A. \& Ojo, L. B. (2008). Staff training and development: A vital tool for organisational effectiveness. European Journal of Scientific Research, 24 (3), 326-331.

[18] Olukayode, L. (2015). Impact of workplace conflict management on organizational performance: A case of Nigerian manufacturing firm. Journal of Management and Strategy, 6 (2), 83- 92.

[19] Rajinder, M. A. (2002). Towards a theory of managing organizational conflict. The International Journal of Conflict Management, 13 (20), 1-12.

[20] Richard, P. J., Devinney, T. M., Yip, G. S. \& Johnson, G. (2009). Measuring organizational performance: Towards methodological best practice. Journal of Management, 35 (3), 718- 804 . 
[21] Sule, O., \& Amuni, S. (2014). Wages and Salaries Administration as Motivational Tool in Nigerian Organization. Journal of Business Theory and Practice, 2 (2) 247-266.
[22] Theresa, I. N. \& Henry, C. E. (2016) Impact of conflict management on employees performance: A study of Nigerian Breweries Plc, Iganmu, Lagos State, Nigeria. European Journal of Business and Management, 8 (8), 70-76. 